\title{
Notes on the Biology of Certain Lamellibranchs on the Scottish Coast.
}

By

\author{
A. C. Stephen, B.Sc., F.R.S.E.,
}

Royal Scottish Museum, Edinburgh.

With 15 Figures in the Text.

\section{CONTENTS.}

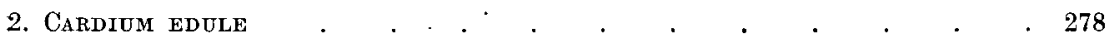

(a) Introductory . . . . . . . . . . . . . . . 278

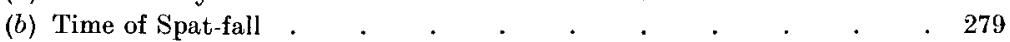

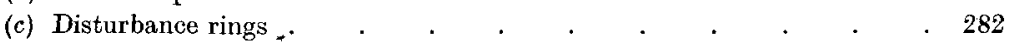

(d) Age-composition of Cardium on the Hunterston Sands . . . 283

(e) Size at each winter ring. 1930 spat, Stns. $8,13,18,21 \quad$. $\quad .284$

1929 . . . . . . . . . 284

$1928 \quad \% \quad . \quad . \quad . \quad . \quad . \quad . \quad .285$

$1927 \% \quad . \quad . \quad$. . . . $\quad .285$

$1926, \quad . \quad . \quad . \quad . \quad . \quad . \quad . \quad .287$

Spat of 1925 and previous years . . . 288

Kilchattan Bay, Bute $\quad$. . . . 289

(f) Differences in the rate of growth between H.W.M. and L.W.M. . . 290

3. Tellina tenuis . . . . . . . . . . . . 291

(a) Variations in quantity of spat and in total population . . . . 291

(b) Variation in density of population . . . . . . . . . 293

(c) Rise and decline of the 1926 spat . . . . . . . . . . . . . . . . . .

4. Macoma baltica . . . . . . . . . . . . . 296

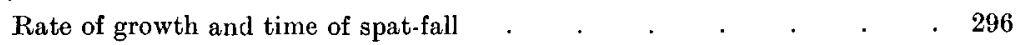

5. Summary . $\cdot$.

6. Literature cited . . . . . . . . . . . . 299

\section{Introduction.}

CASUAL observations on Cardium at Millport not agreeing closely with Orton's account of his work at Plymouth (2), it was felt that there might be important differences between the two areas which would make an investigation in the Millport area of interest and importance. Further, Millport is very favourably situated for such observations since the rich, 
extensive and little disturbed cockle-beds on the Hunterston Sands are of easy access from the Laboratory. The growth and spatting of the species have been studied for a year, from the autumn of 1929 until the autumn of 1930. The results so far obtained seem of sufficient importance to warrant a preliminary account, and it is hoped later to deal with several other points in the biology of Cardium which at present are not sufficiently clear.

The observations on Tellina tenuis at Stn. 5 in Kames Bay, Cumbrae, are summarised.

An attempt has also been made to carry out similar work with Macoma baltica in the Firth of Forth. It is unfortunate that this species is not present in the necessary quantity at Millport to give results comparable with those for Cardium and Tellina.

The methods used throughout have been those originally adopted for studying Tellina tenuis. Unless otherwise stated collections have been made with a 2-mm. sieve, and from an area of $\frac{1}{4} \mathrm{sq}$. m. dug to a depth of $15 \mathrm{~cm}$. The "length " of the shell, or annual ring, has been taken as the measurement in a straight line of the greatest antero-posterior diameter. All measurements have been taken to the nearest $\mathrm{mm}$. above, e.g. all specimens from $4 \cdot 1$ to $5 \cdot 0 \mathrm{~mm}$. have been counted as $5 \mathrm{~mm}$. The total length of the shell has been measured on a measuring board, and the measurements of the annual rings have been made with a pair of fine dividers.

For part of the material and for the facilities which I have enjoyed at, the Millport Marine Station, I am indebted to the superintendent, Mr. Elmhirst, without whose ungrudging assistance the work could not have been accomplished.

\section{Cardium edule.}

\section{(a) Introductory.}

Johnstone (1) states that Cardium edule breeds during spring and summer, this conclusion having evidently been reached from an examination of the reproductive organs. As we now know, however, this is not always a safe guide since many species carry apparently ripe reproductive products for a considerable time before spawning. Orton (2) largely accepts his conclusion and considers that all specimens without a welldefined ring on the shell are spatted in the same year. He also concludes that the first of the several conspicuous rings usually seen on a large shell represents the first winter ring. While this may be the case at Plymouth it is not borne out by the observations at Millport. As will be shown later, however, the evidence on which Orton based his conclusions is open to an alternative interpretation. The conclusions reached regarding the time of spatting at Millport have been drawn, not from the doubtful 
evidence of the state of the reproductive organs, but from the time of appearance of very small cockles at various stations. The evidence drawn from the observations made at Millport during 1929 and 1930 seems to point conclusively to $(a)$ a summer breeding period and $(b)$ to the ring laid down in the first winter being faint and easily overlooked, the first conspicuous ring being the second, not the first, winter ring.

The observations were carried out on the Hunterston Sands, which lie on the Ayrshire coast opposite the Cumbrae, and have a length of about three miles and a maximum width of about a mile at low tide. Previous to the main experiment a general survey was undertaken in the autumn of 1929 during which 26 stations, equally spaced over the sands, were examined. At each station the sand, or muddy sand, was dug out to a depth of $15 \mathrm{~cm}$. from an area of $\frac{1}{4} \mathrm{sq} . \mathrm{m}$. and run through a $1-\mathrm{mm}$. sieve. From the results of this survey four stations, representing the chief types of the Cardium ground, were selected for further work. These stations were as follows :-

Stn. 8. North-east part of the sands, about half-tide, in the middle of a rich cockle bed.

Stn. 13. Near H.W.M. at the upper edge of this bed close to the Black Rocks.

Stn. 18. In the middle of the sands north of Poteath, about half-tide, where the Tellina and Cardium grounds overlap.

Stn. 21. South-west end of the sands about half-tide, in the middle of a rich cockle bed.

\section{(b) TIME OF SPAT-FALL.}

Of the four stations No. 21 was most intensively worked and may conveniently be discussed separately.

\section{TABLE I.*}

Table showing the Rate of Growth of the 1929 Spat during 1930, and the Trme of Appearance of the 1930 Spat at Stn. 21.

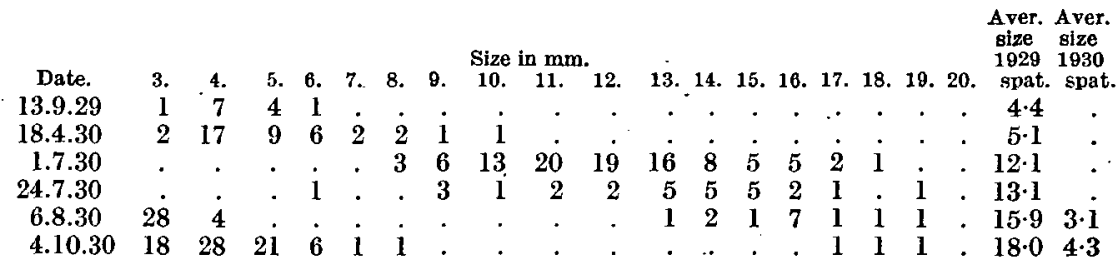

* Since the older individuals do not come under review in this paragraph, the table is confined to specimens under $21 \mathrm{~mm}$. in length, the rest of the collections being dealt with later. 
In September, 1929, a group of very small cockles, ranging from 3 to $6 \mathrm{~m}$.m., was found, but from 7 to $21 \mathrm{~mm}$. there was a hiatus. Growth starts early in spring, but collecting was delayed until April so that the new year's growth should have had time to show, and the nature of the winter ring laid down by these fragile spat could be seen. In passing it may be remarked that in most of the specimens this ring was narrow and insignificant, but the original small shell could usually be distinguished by its darker colour.

In the April collection, while some shells had reached a length of $10 \mathrm{~mm}$., the majority were still from 4 to $6 \mathrm{~mm}$. in length, with an average size of $5 \cdot 1 \mathrm{~mm}$.; that is practically the same as in autumn. From April onwards growth was rapid, and in the beginning of July the young cockles ranged from 8 to $18 \mathrm{~mm}$. with an average size of $12 \cdot 1 \mathrm{~mm}$. No specimens under $7 \mathrm{~mm}$. were taken. Three weeks later the range was from 9 to $19 \mathrm{~mm}$., with the exception of one specimen at $6 \mathrm{~mm}$., and the average size was $13 \cdot 1 \mathrm{~mm}$.

By the beginning of August a great change had taken pace. The spat of 1929 now ranged from 13 to $19 \mathrm{~mm}$. with an average size of $15.9 \mathrm{~mm}$.; and a new group of small individuals ranging up to $4 \mathrm{~mm}$. in lengththe 1930 spat-had appeared. The figures, so far, all refer to the collections made with the $2-\mathrm{mm}$. sieve, but, in addition small samples of sand were run through a 1-mm. sieve as a check on new spat. Until August this procedure had shown that all the young cockles were being retained by the 2-mm. sieve, but in August it was evident that the numbers of cockles retained by the 2-mm. sieve represented only a small. fraction of the spat, since from an area of $\frac{1}{4} \mathrm{sq}$. m. 51 cockles passed the 2-mm. sieve and were retained by the 1-mm. sieve.

By the beginning of October the 1929 spat was very much reduced in numbers, and only three specimens, ranging from 17 to $19 \mathrm{~mm}$., were taken. The 1930 spat then ranged up to $8 \mathrm{~mm}$. with an average size of $4.3 \mathrm{~mm}$., and both its size-frequency and average size were similar to those of the 1929 spat.

Similar remarks apply to the other stations. At Stn. 8, for example (Table II), in September, 1929, there was a group of small individuals ranging from $3 \mathrm{~mm}$. to $5 \mathrm{~mm}$. By the end of May, 1930, the range was from $4 \mathrm{~mm}$. to $13 \mathrm{~mm}$. and the average size was $8.6 \mathrm{~mm}$. A month later the range was from $7 \mathrm{~mm}$. to $16 \mathrm{~mm}$. and the average size $10.7 \mathrm{~mm}$. No further collection was made until October, when only four specimens of the $1929 \mathrm{brood}, 15 \mathrm{~mm}$. to $19 \mathrm{~mm}$., and only two specimens of the 1930 brood were taken. The collection taken in the beginning of December contained only seven specimens of the 1930 spat and none of the 1929 spat.

At Stn. 13 also a group of small individuals ranging from $3-7 \mathrm{~mm}$. was present in September, 1929. By the end of May the range was from 
$5 \mathrm{~mm}$. to $14 \mathrm{~mm}$. and the average size was $8.1 \mathrm{~mm}$. A month later the range was from $6 \mathrm{~mm}$. to $15 \mathrm{~mm}$. and the average size was $10.9 \mathrm{~mm}$. In the beginning of October only one specimen of the 1929 spat was taken, but the new 1930 spat was present as a group of small individuals from $3 \mathrm{~mm}$. to $5 \mathrm{~mm}$. In the collection taken in the beginning of December the 1929 spat was found to range from $15 \mathrm{~mm}$. to $19 \mathrm{~mm}$. The range of the 1930 spat had increased and was from $3 \mathrm{~mm}$. to $8 \mathrm{~mm}$., but most of the specimens were under $7 \mathrm{~mm}$. in length.

Stn. 18 was only sampled in the autumns of 1929 and 1930 . Both in range and average size the spats of the two years were very similar, that of 1930 being, on the whole, rather more numerous.

\section{TABLE II.}

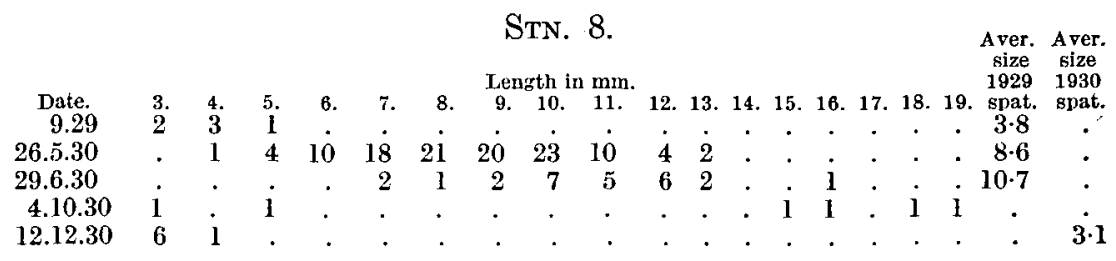

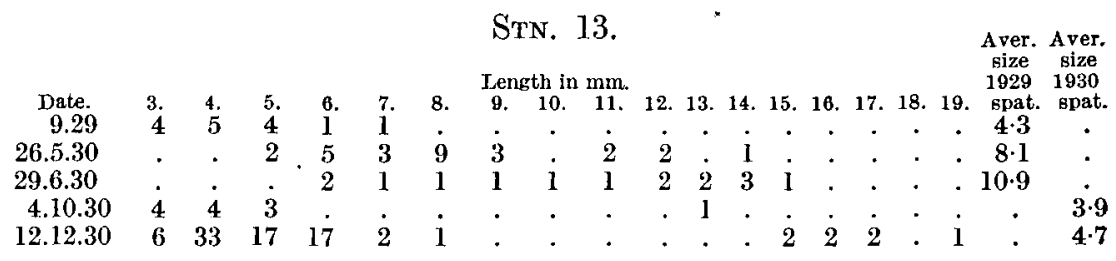

STN. 18.

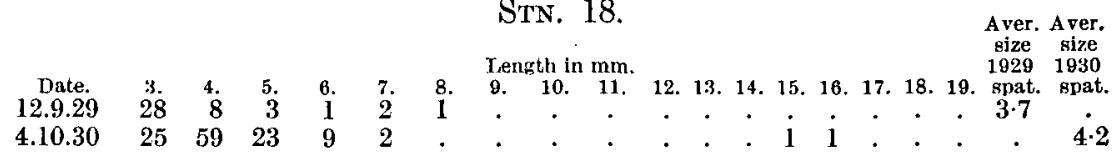

These results indicate that at Millport the cockle breeds in summer and that the spat is to be found on the ground towards the end of August. Of the spat some few individuals may reach a size of $10 \mathrm{~mm}$. before winter, but most are under $6 \mathrm{~mm}$. The winter ring laid down by these small shells is usually visible if looked for carefully. It is easily seen in young specimens up to one or two years of age, but in older shells, especially if there has been any erosion, the ring is often quite obliterated.

Further evidence confirming the time of spatting has been got from the state of the reproductive organs which, at Millport, seem to be ripe from about the end of July. Spawning has only once been observed. Some cockles taken on the 1st July, 1930, were put in a jar and next day, on 
being given fresh water, proceeded to emit clouds of eggs and sperms. The sperms were active and clustered round each egg, but further development did not take place.

Reference has already been made to Orton's paper (2). Much of what he says is applicable to the Millport cockles, the great point of divergence is in the estimate of what constitutes the first winter ring. Orton in his figure (2, p. 251) undoubtedly calls the first distinct ring on the shell, apart from marking rings, the first winter ring, whereas in the Millport specimens this is the second winter ring. His experiment, however, while suitable for studying the growth of Cardium was not suitable for studying its spat fall. The experiment was conducted by placing marked cockles of varying size in a box moored in the river, and, to allow fresh water to flow through, the sides were covered with material having perforations $6 \mathrm{~mm}$. in diameter. The box was opened periodically and the cockles examined. During spring and summer, in addition to the original large cockles, Orton found a number of small ones. These he assumed were spat carried in by the currents. While there is a possibility that this may have been the case, the more probable explanation is that these small cockles were some of the previous autumn brood which had either been washed into the box or had climbed in. The box was near the bottom of the river and it was quite possible for material from the bottom to be washed in as Orton admits (2, p. 253). The possibility that the small cockles may have climbed in is not at all improbable as the following observation shows. A number of small cockles about $4 \mathrm{~mm}$. in length, were placed in a dish containing sea-water. One of these climbed up the side of the vessel to a height of about $2 \mathrm{~cm}$. above the water, and repeated this twice when pushed back. The perforations in Orton's box were $6 \mathrm{~mm}$. in diameter and, at Millport at least, even in early summer it is possible to find cockles of the previous autumn spat at this size. The smallness of the immigrating cockles, therefore, does not necessarily point to their being new spat. The question of time of spat fall is important, since on it depends the correct reading of the rings, and it would be of great value to have the question reinvestigated at Plymouth to decide if the breeding period of cockles in the two areas is really so different.

\section{(c) DISTURBANCE RINGS.}

Orton found that a ring was formed on the shell whenever the cockles were taken out and marked. These "false" or " disturbance rings" were similar in appearance to the true winter rings, and would have been read as such by anyone unacquainted with the history of the particular specimen. Practically all the cockles taken at Millport were of the same type, that is, they had the first two or three obvious rings on the shell separated by fairly large intervals. Only some half-dozen specimens 
departed from this type in that instead of one ring there were two very close together. These are similar to the disturbance rings figured by Orton. In the cockle beds from which the collections were taken it would appear that disturbance rings are only found in a small percentage of the shells.

(d) AGE-COMPOSTTION OF THE CARDIUM ON THE HUNTERSTON SANDS.

The material on which this and the subsequent paragraph are based consists of the quantitative collections from the regular stations, supplemented by three large collections from an unmeasured area of shore at Stns. 8 and 21. In addition, two other collections from the Hunterston Sands and one from Kilchattan Bay in Bute are included since they throw light on some particular point. The numbers are not sufficient to allow of any estimate of the rate of mortality or of the proportions of the various year-groups in the population before and after spatting. The collections from each station have been considered as a whole. Some few of the specimens in which the number of rings was not clear, e.g. those showing disturbance rings, have been left out of consideration.

\section{TABLE III.}

Showing the Proportion of each year's Spat in the Collections From Each Station CONSIDEREd aS a whole.

$\begin{array}{rccccrrrrr}\text { Stn. } & 1920 . & 1921 . & 1922 . & 1923 . & 1924 . & 1925 . & 1926 . & 1927 . & 1928 . \\ 8 & . & . & . & . & 7 & 17 & 189 & 19 & 24 \\ 13 & . & . & 2 & 1 & 6 & 15 & 26 & 10 & 17 \\ 18 & . & 1 & . & 1 & 1 & 10 & 18 & 5 & 4 \\ 21 & 1 & 4 & 8 & 8 & 14 & 21 & 279 & 57 & 40\end{array}$

Specimens spatted in all years from 1920 were taken and the numbers belonging to each year-group are set out in Table III, the spat of the years 1929 and 1930 excepted since they have been fully dealt with already.

The group spatted in 1926 was the dominant group at all stations, especially at Stns. 21 and 8 in the middle of the beds where density is greatest. At Stns. 13 and 18, at the landward and seaward edges of the beds, it was almost rivalled in numbers by the survivors of the 1925 spat. A supplementary collection from a position 100 yards landwards from Stn. 21 yielded 27 cockles from $\frac{1}{4} \mathrm{sq}$. $\mathrm{m}$. of ground, and of these 21 were spatted in 1926.

This preponderance of the 1926 spat is significant when compared with the similar predominance of the 1926 spat of Tellina in Kames Bay. The observations on Tellina were made in a very small area, but the figures for Cardium are drawn from stations about a mile apart and on the other 
side of the channel from Kames Bay. Taking the two sets of results into consideration the summer of 1926 seems to have been unusually favourable for the spatting of both Cardium and Tellina, and possibly other species as well. The causes of these variations have not yet been determined.

The predominance of the cockles spatted in 1926 over the other yeargroups during the period 1926-1930, seems to have extended beyond the comparatively small area on the east side of the Cumbrae covered by these experiments. On the opposite side of the Cumbrae, and separated from it by about 3 miles of sea, lies Kilchattan Bay in Bute. A collection of cockles from near H.W.M. in the spring of 1929 gave the following distribution of year-groups :-

$\begin{array}{llllr}1924 \text { spat } & . & . & . & 11 \\ 1925 " & . & . & . & 3 \\ 1926 " & . & . & . & 15 \\ 1927 \text { " } & . & . & . & 2 \\ 1928 \text { " } & . & . & . & 0\end{array}$

This would point to the survival of the 1926 spat in unusual quantities over a fairly wide area. It is not possible at present to say just how far that area extended.

\section{(e) SIZE AT EACH WINTER RING.}

The size of each winter ring in the survivors of the successive broods has been calculated, but, except in the case of the 1926 spat, the numbers are so small that only a general summary has been given.

\section{Spat. (Tables I and II.)}

In the beginning of August this was found at Stn. 21. The other stations were not examined at this time, but this spat would certainly have been found at them also. By the beginning of October at Stn. 21 the range extended up to $8 \mathrm{~mm}$., but most of the specimens were not over $5 \mathrm{~mm}$. in length. At Stn, 18 the range in October extended up to $7 \mathrm{~mm}$., as at Stn. 21, however, most of the specimens were under $5 \mathrm{~mm}$. At Stn. 13 only a few specimens ranging up to $5 \mathrm{~mm}$. were taken. At Stn. 8 the October collection yielded only a few spat, and its scarceness at this station was emphasised by the December collection, when only 7 specimens were taken from $\frac{1}{4}$ sq. m. of ground. On the other hand, a collection taken at Stn. 13 in December gave 76 specimens per $\frac{1}{4} \mathrm{sq}$. m. These ranged up to $8 \mathrm{~mm}$. in length, but the majority were below $6 \mathrm{~mm}$.

\section{Spat. (Tables I and II.)}

The individuals belonging to this group, like those spatted in 1930, showed no well-marked ring, only the faint first winter ring being visible. The first clear ring would be laid down in the winter 1930-31. Briefly 
summarised-this group spatted in the late summer of 1929 was found at all stations in September of that year, ranging up to $8 \mathrm{~mm}$. in length. During the following year it gradually decreased in abundance and was comparatively scarce by the end of 1930 , the survivors then being between 15 and $19 \mathrm{~mm}$. in length.

There is naturally a certain amount of variation from sample to sample, but during the year the numbers steadily declined and this was confirmed by an examination of the shore in October when the empty shells were lying everywhere. This raises the question as to whether the modes and means at various periods of the year, e.g. Tables I and II, represent the actual rate of growth of the survivors. I think they do not and that they are consistently too low. Some individuals of a group grow quickly from the start, others slowly, and it seems to be amongst the slower growing members that mortality is greatest.

\section{Spat. (Table IV.)}

The cockles spatted in 1928 and taken during 1930 had only one welldefined ring on the shell, namely, the 1929-30 winter ring. They were not very plentiful. At Stn. 18 only four specimens were taken, and need not be considered. Those taken at Stns. 21 and 8 were alike, in that the range was large, $15-25 \mathrm{~mm}$. and $14-26 \mathrm{~mm}$. respectively, and the means much the same, $20.6 \mathrm{~mm}$. and $20.3 \mathrm{~mm}$., but differed from those taken at Stn. 13 where it was small, $15-20 \mathrm{~mm}$., and the mean low, $17 \cdot 4 \mathrm{~mm}$.

\section{TABLE IV.}

Showing the Size-Frequency in mm. of the 1929-30 Winter Ring IN THE 1928 SPAT.

$\begin{array}{rcccccccccccccc}\text { Stn. } & 14 . & 15 . & 16 . & 17 . & 18 . & 19 . & 20 . & 21 . & 22 . & 23 . & 24 . & 25 . & 26 . & \text { Mean. } \\ 21 & . & 1 & 1 & . & 2 & 10 & 4 & 7 & 7 & 4 & 3 & 1 & . & 20 \cdot 6 . \\ 18 & . & . & 1 & . & 1 & . & . & . & . & . & 2 & . & . & . \\ 13 & . & 5 & 1 & 2 & 2 & 5 & 2 & . & . & . & . & . & . & 17 \cdot 4 \\ 8 & 1 & . & 2 & 1 & 4 & 3 & 3 & 2 & . & 3 & 2 & 2 & 1 & 20 \cdot 3\end{array}$

1927 Spat. (Table V.)

The individuals derived from this spat and taken in September, 1929, had only one well-marked ring, the 1928-29 winter ring, while those taken during 1930 had two, the 1928-29 and 1929-30 winter rings. This was the scarcest of all the recent year-groups and, except at Stn. 21, only a few were taken.

\section{8-29 Winter Ring.}

At Stn. 21 the range was from $14 \mathrm{~mm}$. to $27 \mathrm{~mm}$. and the mean was $20.8 \mathrm{~mm}$. At Stn. 8 the range was rather narrower, but the mean was 
about the same. At Stn. 13 the range was narrower and the mean less than at either of these two stations.

1929-30 Ring.

At Stn. 21 the range was from $22 \mathrm{~mm}$. to $37 \mathrm{~mm}$. and the mean was at $29.8 \mathrm{~mm}$. At Stn. 13 the range was narrower, $24-28 \mathrm{~mm}$., and the mean less, $26 \cdot 4 \mathrm{~mm}$.

\section{TABLE $V$.}

Showing the Size-Frequency of the 1928-29 and 1929-30 Winder RINGS IN THE 1927 SPAT.

1928-1929 RING.

$$
\begin{array}{rccccccccccccccccc}
\text { Stn. } & 14 & 15 & 16 & 17 & 18 & 19 & 20 & 21 & 22 & 23 & 24 & 25 & 26 & 27 & 28 & 29 & \text { Mean. } \\
8 & . & . & . & 1 & 1 & . & 2 & 6 & 3 & 1 & 1 & . & . & . & . & . & 20 \cdot 9 \\
13 & . & . & 1 & . & 1 & 2 & 1 & 4 & 1 & . & . & . & . & . & . & . & 19 \cdot 6 \\
18 & . & . & . & . & . & . & . & 2 & 1 & . & . & 1 & 1 & . & . & . & . \\
21 & 2 & . & 1 & 4 & 4 & 9 & 7 & 6 & 9 & 7 & 4 & 1 & 2 & 1 & . & . & 20 \cdot 8
\end{array}
$$

1929-1930 Ring.

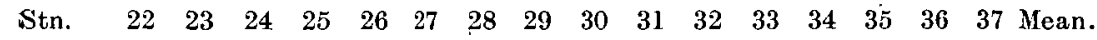

$\begin{array}{rlllllllllllllllll}8 & . & . & . & . & . & 1 & 1 & 2 & 5 & 2 & 1 & . & 1 & 1 & . & . & 30 \cdot 4 \\ 13 & . & . & \text { 1 } & 2 & \text { 1 } & 4 & 2 & . & . & . & . & . & . & . & . & . & 26 \cdot 4 \\ 18 & . & . & \text {. } & . & . & . & 1 & 2 & . & . & . & 1 & \text {. } & . & . & . & . \\ 21 & \text { i } & . & \text { i } & 2 & 7 & 6 & 6 & 9 & 4 & 3 & 2 & 6 & 1 & 3 & 2 & 3 & 29 \cdot 8\end{array}$

TABĹE VI.

Showing the Size-Frequencies of the Winter Rings for THE 1926 Spat.

1927-28 RiNa.

$\begin{array}{rrrrrrrrrrrrrrrrrrrr}\text { Stn. } & 13 & 14 & 15 & 16 & 17 & 18 & 19 & 20 & 21 & 22 & 23 & 24 & 25 & 26 & 27 & 28 & 29 & 30 & \text { Mean. } \\ 8 & 1 & . & . & 3 & 5 & 5 & 16 & 21 & 33 & 22 & 23 & 11 & 26 & 8 & 11 & 1 & 2 & 1 & 22 \cdot 3 \\ 13 & 1 & . & . & 1 & 1 & 5 & 5 & 7 & 3 & 1 & 1 & 1 & . & . & . & . & . & . & 19 \cdot 3 \\ 18 & . & . & . & . & . & . & . & 3 & 2 & 3 & 2 & 6 & 1 & 1 & . & . & . & . & 22 \cdot 7 \\ 21 & . & 2 & . & 1 & 5 & 7 & 18 & 38 & 30 & 54 & 53 & 28 & 24 & 13 & 4 & 2 & . & . & 22 \cdot 4\end{array}$ 1928-29 Rina.

$\begin{array}{llllllllllllllllllll}\text { Str. } & 22 & 23 & 24 & 25 & 26 & 27 & 28 & 29 & 30 & 31 & 32 & 33 & 34 & 35 & 36 & 37 & 38 & 39 & \text { Mean. }\end{array}$

$\begin{array}{llllllllllllllllllll}8 & . & . & 1 & 2 & 3 & 7 & 17 & 17 & 26 & 25 & 26 & 18 & 14 & 16 & 11 & 3 & 2 & 1 & 31 \cdot 2\end{array}$

$\begin{array}{lllllllllllllllllllll}13 & 1 & 4 & 1 & 6 & 4 & 2 & 4 & 2 & 2 & . & . & . & . & . & . & \text {. } & . & . & 25 \cdot 2\end{array}$

$\begin{array}{lllllllllllllllllllll} & 18 & . & . & . & . & . & 1 & 2 & 4 & 4 & 3 & \mathrm{i} & . & . & 2 & . & \mathrm{i} & . & . & 30 \cdot 6\end{array}$

$\begin{array}{llllllllllllllllllll}21 & \mathrm{l} & \ldots & 2 & 3 & 6 & 8 & 27 & 43 & 50 & 57 & 40 & 20 & 15 & 5 & 2 & . & . & . & 30 \cdot 4\end{array}$

1929-30 RING.

$\begin{array}{llllllllllllllllllll}\text { Stn. } 25 & 26 & 27 & 28 & 29 & 30 & 31 & 32 & 33 & 34 & 35 & 36 & 37 & 38 & 39 & 40 & 41 & 42 & 43 & 44 \\ \text { Mean. }\end{array}$

$\begin{array}{rrrrrrrrrrrrrrrrrrrrrr}8 & . & . & . & . & . & 1 & 8 & 11 & 14 & 21 & 31 & 26 & 23 & 20 & 9 & 17 & 3 & 3 & . & 2 & 36 \cdot 0 \\ 13 & \text { 1 } & 3 & 2 & 5 & 4 & 2 & 2 & 4 & 2 & 1 & . & . & . & . & . & . & . & . & . & . & 29 \cdot 3 \\ 18 & . & . & . & . & . & 1 & 1 & 4 & 5 & 1 & 1 & 2 & . & 2 & . & 1 & . & . & . & . & 33 \cdot 9 \\ 21 & . & . & . & \text { i } & . & 7 & 21 & 31 & 40 & 46 & 52 & 41 & 27 & 5 & 5 & 2 & 1 & . & . & . & 34 \cdot 2\end{array}$

1930-31 RrNa.

Stn. $\begin{array}{lllllllllll}33 & 34 & 35 & 36 & 37 & 38 & 39 & 40 & 41 & 42 & \text { Mean. }\end{array}$

$\begin{array}{lllllllllllll}8 & 3 & 3 & 3 & 3 & 5 & 3 & 3 & 1 & \text {. } & 1 & 36 \cdot 5\end{array}$

$\begin{array}{llllllllllllllll} & 18 & 1 & 1 & . & 3 & 1 & 2 & . & . & . & . & 36 \cdot 0\end{array}$ 


\section{Spat. (Table VI.)}

The specimens taken during September, 1929, had two well-marked rings, and those taken during 1930 had three well-marked rings. The length of specimens taken October and December, 1930, may be taken as the equivalent of the 1930-31 winter ring, which would just be beginning to be laid down. The size-frequencies and means of the various winter rings are set out in Table VI.

\section{7-28 Winter Ring.}

At Stn. 8 the range was from 13 to $30 \mathrm{~mm}$., but in most of the specimens was between 19 and $27 \mathrm{~mm}$., and the mean size was $22.3 \mathrm{~mm}$. At Stns. 13 and 18 comparatively few specimens were taken and on these the range was from 13 to $24 \mathrm{~mm}$. with the mean at $19.3 \mathrm{~mm}$. in the first case, and from 20 to $26 \mathrm{~mm}$. with the mean at $22.7 \mathrm{~mm}$. in the second case. At Stn. 21 the range was from 14 to $28 \mathrm{~mm}$., but in most of the specimens was between 18 and $27 \mathrm{~mm}$., and the mean was at $22.4 \mathrm{~mm}$. The means at Stns. 8,18 , and 21 were all very nearly the same, but the mean at Stn. 13 was considerably lower.

\section{8-29 Winter Ring.}

At Stn. 8 the range was from 24 to $39 \mathrm{~mm}$., but as before most of the measurements were confined within narrower limits, namely, 28 to $36 \mathrm{~mm}$. The mean was at $31.2 \mathrm{~mm}$. At Stn. 13 the range was from 22 to $30 \mathrm{~mm}$. and the mean was at $25 \cdot 2 \mathrm{~mm}$. At Stn. 18 the range was from 27 to $37 \mathrm{~mm}$. and the mean was $30.6 \mathrm{~mm}$. At $\mathrm{Stn}$. 21 the range was again large, being from 22 to $36 \mathrm{~mm}$.; as before the majority of the rings were confined within narrower limits, namely, $28 \mathrm{~mm}$. to $34 \mathrm{~mm}$. The mean was at $30.4 \mathrm{~mm}$. As before the mean at Stn. 13 was considerably below the means of the other stations.

\section{9-30 Winter Ring.}

At Stn. 8 the range was from 30 to $44 \mathrm{~mm}$., but most of the figures lay between 32 and $40 \mathrm{~mm}$., with the mean at $36.0 \mathrm{~mm}$. At Stn. 13 the range was from 25 to $34 \mathrm{~mm}$. and the mean was at $29 \cdot 3 \mathrm{~mm}$. At Stn. 18 the range was from 30 to $40 \mathrm{~mm}$. and the mean was at $33.9 \mathrm{~mm}$. At Stn. 21 the range was from 28 to $41 \mathrm{~mm}$., but most of the figures lay between 30 and $38 \mathrm{~mm}$., with the mean at $34 \cdot 2 \mathrm{~mm}$.

\section{0-31 Winter Ring.}

The October and December measurements of the lengths of the shell may be taken as representing approximately the size of this ring. Since only very few specimens were taken at Stns. 13 and 21 these stations have not been included in Table VI. 
At Stn. 8 the range was from 33 to $42 \mathrm{~mm}$. and the mean was at $36.5 \mathrm{~mm}$. At Stn. 18 the range was from 33 to $38 \mathrm{~mm}$. with the mean at $36.0 \mathrm{~mm}$.

Spat of 1925 and Previous Years. (Table VII.)

Very few of the cockles spatted in these years were found in the collections, and no useful purpose would be served by considering the sizefrequencies of the various winter rings in detail, but for comparison the means of the various winter rings have been calculated. Table VIT.

\section{TABLE VII.}

Table Showing the Mean Size of the successive Distinct Rings on each Year's Spat at the various Stations. Where only one OR tWo Specimens Were PRESENT the Average has NOT BEeN Calculated. At Stns. 8 and 13 the pResumed Length of the 1930-31 Ring is included. The Material was Collected during 1929 AND 1930.

\begin{tabular}{|c|c|c|c|c|c|c|c|c|c|}
\hline & & & & STN. & & & & & \\
\hline 1921 & $20 \cdot 5$ & $30 \cdot 2$ & 35.8 & $39 \cdot 2$ & $42 \cdot 0$ & $44 \cdot 5$ & $46 \cdot 0$ & $47 \cdot 2$ & . \\
\hline 1922 & $22 \cdot 4$ & $32 \cdot 4$ & $37 \cdot 0$ & $40 \cdot 1$ & $42 \cdot 9$ & $44 \cdot 9$ & $46 \cdot 2$ & . & . \\
\hline 1923 & $22 \cdot 2$ & $32 \cdot 1$ & $37 \cdot 2$ & $40 \cdot 3$ & $42 \cdot 8$ & $44 \cdot 1$ & . &. & . \\
\hline 1924 & $22 \cdot 7$ & 32.5 & $37 \cdot 2$ & $39 \cdot 3$ & $40 \cdot 6$ & . & & . & . \\
\hline 1925 & $23 \cdot 0$ & $33 \cdot 0$ & $35 \cdot 6$ & $39 \cdot 2$ & . & . & . & . & . \\
\hline 1926 & $22 \cdot 4$ & $30 \cdot 4$ & $34 \cdot 2$ & . & . & . & . & . & . \\
\hline 1927 & $20 \cdot 8$ & $29 \cdot 8$ & . & . & . & . & . & . & . \\
\hline 1928 & $20 \cdot 6$ & . & . & . & . & . & . & . & . \\
\hline & & & & STN. & & & & & \\
\hline 1925 & $23 \cdot 6$ & $33 \cdot 2$ & $35 \cdot 9$ & $38 \cdot 1$ & . & . & . & . & . \\
\hline 1926 & $22 \cdot 7$ & $30 \cdot 6$ & 33.9 & . & . & . & . & . & . \\
\hline & & & & STN. & & & & & \\
\hline 1924 & $22 \cdot 8$ & $28 \cdot 7$ & $31 \cdot 7$ & $33 \cdot 8$ & $35 \cdot 7$ & $38 \cdot 0$ & . & . & \\
\hline 1925 & 19.8 & $25 \cdot 5$ & 28.7 & $31 \cdot 1$ & . & . & . & . & \\
\hline 1926 & $19 \cdot 3$ & $25 \cdot 2$ & $29 \cdot 3$ & . & . & . & & . & . \\
\hline 1927 & $19 \cdot 6$ & $26 \cdot 4$ & . & . & . & . & . & & \\
\hline 1928 & $17 \cdot 4$ & . & . & . & . & . & . & . & . \\
\hline & & & & STN. & & & & & \\
\hline 1924 & $25 \cdot 9$ & $35 \cdot 6$ & $39 \cdot 3$ & $41 \cdot 3$ & $42 \cdot 6$ & . & . & . & . \\
\hline 1925 & $21 \cdot 1$ & $28 \cdot 2$ & $33 \cdot 1$ & $35 \cdot 4$ & 37.8 & . & . & . & \\
\hline 1926 & $22 \cdot 3$ & $31 \cdot 2$ & 36.0 & 36.5 & . & . & . & . & \\
\hline 1927 & $20 \cdot 9$ & $30 \cdot 4$ & . & . & & . & . & . & . \\
\hline 1928 & $20 \cdot 3$ & & . & . & & . & . & . & . \\
\hline
\end{tabular}


In all but the 1926 year-group the numbers are too few to allow of much reliance being placed on the means, especially considering the wide range of the size-frequency figures for any one ring, e.g. Tables I, II, and IV, but the figures are fairly consistent. For any one station the means of the older groups are distinctly higher than those of the younger groups, and this would point to the suggestion already made that mortality tends to be heaviest at the lower end of the size-frequency scale.

It is interesting to compare this table with Orton 2, p. 250, Table II, showing the rate of growth of his marked cockles. Their rate of growth corresponds fairly well with that at Stn. 21, i.e. an average section from a natural bed and, except for the difference in the estimation of what constitutes the first winter ring, the two investigations are confirmatory.

In addition to the collections from the regular stations two others from these sands may be mentioned. One sample taken on the 16.8.30, from a position 100 yards landwards from Stn. 21, contained 27 cockles per $\frac{1}{4} \mathrm{sq}$. m. This position was roughly intermediate between Stns. 21 and 13 as regards level and, as was to be expected, both the range and means were intermediate between those of these two stations, e.g.

1927-28 Ring. . 1928-29 Ring. 1929-30 Ring.

Range 17-24 mm. Range 23-31 mm. Range 27-33 mm.

Mean $20.5 \mathrm{~mm}$. Mean $27.8 \mathrm{~mm}$. Mean $30.5 \mathrm{~mm}$.

Another collection was taken in July at some distance to the seaward of Stn. 21 beyond the cockle beds proper, and in the Tellina ground where only few and large cockles occur. (Stn. 16.) A $\frac{1}{4}$ sq. m. sample yielded 7 cockles which were remarkable for their large growth, e.g. Table VIII.

\section{TABLE VIII.}

\begin{tabular}{|c|c|c|c|c|c|c|c|}
\hline $\begin{array}{l}1925-6 \\
\text { Ring. }\end{array}$ & $\begin{array}{c}1926-7 \\
\text { Ring. }\end{array}$ & $\begin{array}{l}1927-8 \\
\text { Ring. }\end{array}$ & $\begin{array}{l}\text { 1928-9 } \\
\text { Ring. }\end{array}$ & $\begin{array}{c}\text { 1929-30 } \\
\text { Ring. }\end{array}$ & $\begin{array}{l}\text { Total } \\
\text { length } \\
1.7 .30 .\end{array}$ & $\begin{array}{l}\text { Spatted } \\
\text { in autumn } \\
\text { of }\end{array}$ & \\
\hline 33 & 44 & 52 & 53 & 54 & 54 & 1924 & 1928 Spat. \\
\hline . & . & . & 27 & 38 & 44 & 1927 & 1929-30 Ring. \\
\hline . & . & . & 24 & 35 & 39 & , & Mean $27.3 \mathrm{~mm}$. \\
\hline . & . & . & . & 27 & 37 & 1928 & \\
\hline . & . & . & . & 29 & 35 & ," & \\
\hline . & . & . & . & 27 & 34 & ," & \\
\hline . & . & . & . & 26 & 33 &, & \\
\hline
\end{tabular}

Kilchattan Bay, Bute.

This collection, already referred to on p. 284, was taken close to H.W.M., 29.3.29, and the means would be expected to compare with those of Stn. 13 . This is actually the case, as may be seen by comparing with Stn. 13 the 
specimens spatted in 1924 and 1926, of which 11 and 15 specimens, respectively, were taken.

$\begin{array}{rcccc} & \text { Ring. } & \text { Ring. } & \text { Ring. } & \text { Ring. } \\ \text { Stn. 13. Hunterston 1926 spat } & \cdot & . & 19 \cdot 3 & 25 \cdot 2 \\ \text { Kilchattan Bay 1926 spat } & . & . & 17 \cdot 9 & 25 \cdot 7 \\ \text { " " 1924 spat } & 20 \cdot 0 & 25 \cdot 8 & 28 \cdot 8 & 31 \cdot 5\end{array}$

(f) DIFFERENCES IN THE RATE OF GROWTH BETWEEN H.W.M.

AND L.W.M.

It has already been shown (Stephen, 5) that the cockle gets smaller from L.W.M. to H.W.M. This could come about in two ways, either by the rate of growth being different at various levels, or by the spat falling in greatest quantity on the upper part of the beach and gradually migrating seawards. The first explanation seems to be the correct one if the means are compared. If migration took place the means of the rings formed in the earlier years of life should be very much the same for all specimens and at all levels, actually the means increase from H.W.M. to L.W.M. Although the following four stations do not lie in a straight line their means may be used to illustrate this difference of growth. The means for the first three stations are those of the 1926 spat and for Stn. 16 that of the 1928 spat. Table IX.

TABLE IX.

\begin{tabular}{|c|c|c|}
\hline Stn. 13. Near H.W.1 & $\begin{array}{r}\text { Ring. } \\
19 \cdot 3\end{array}$ & $\begin{array}{l}\text { Ring. } \\
25 \cdot 2\end{array}$ \\
\hline 100 yards up from Stn. $21 .{ }_{4}^{3}$ tide & $20 \cdot 5$ & $27 \cdot 8$ \\
\hline Stn. 21, half-tide . . & $22 \cdot 4$ & $30 \cdot 4$ \\
\hline tn. 16, near L.W.M. & $27 \cdot 3$ & \\
\hline
\end{tabular}

The cockle therefore increases regularly in size from H.W.M. to L.W.M. In this it resembles Arenicola marina and differs from Tellina tenuis and Donax vittatus.

So far as could be seen almost all the cockles at any station were of the same type, but occasionally at the lower stations a cockle was found which had obviously been washed down from higher up. At Stn. 21, for example, only three of the cockles taken were exceptional in that they had the annual rings much closer together than the rest of the specimens, and corresponded to the type found at the station 100 yards further up the beach.

This summary deals only with some of the more important points in the biology of the cockle, but others are being investigated, and it is hoped at a later date to deal with the species in greater detail. 


\section{Tellina tenuis.}

Observations in Kames Bay have been carried out regularly during the period middle of September, 1926, to end of August, 1930, and while there is little to add to the accounts already published of the rate of growth. and time of spat-fall (Stephen, $\mathbf{3}$ and 4 ), new facts have been gathered. regarding $(a)$ the variations in the quantity of spat and in the total population from year to year, and $(b)$ the growth and final disappearance of the: generation spatted in the autumn of 1926.

\section{(a) VARIATIONS IN THE QUANTITY OF SPAT AND IN THE TOTAL POPULATION.}

In the earlier part of the investigation on Tellina tenuis in Kames Bay, collections were made at several stations, which were later reduced to two, namely, Stn. 2 near H.W.M. neaps and Stn. 5 at L.W.M. springs. Early in 1930 heavy storms completely altered and destroyed much of the upper part of the beach. The continuity of the experiment at Stn. 2 : was therefore broken, but fortunately Stn. 5 was not affected, and a complete record of the size-frequencies of the population from September, 1926, to the end of August, 1930, has been obtained. Regular collections were made in spring, summer, and autumn, and in all but two cases thesewere quantitative. On the two occasions the station was not completely uncovered by the tide and qualitative collections only were obtained. A few supplementary collections were taken from time to time.

The amount of "spat" per unit area in Kames Bay in the autumn of each year is given in Table $X_{A}$, all specimens 3 and $4 \mathrm{~mm}$. in length being: counted as "spat." These figures are probably a slight underestimate.

Spat was not laid down in equal amounts each year. In the autumn of 1926 it was very abundant and formed about $80 \%$ of the population.. In 1927 it was also abundant, but the amount was only about half that of the previous year. Owing to the high rate of survival of the 1926 spat, however, it only formed $36 \%$ of the population. In 1928 spat was fairly plentiful, but again owing to the large number of older individuals on the ground formed only $28 \%$ of the population. Spat was very scarce in 1929 , reaching the comparatively low figure of about 230 per sq. m. ; 1930 was once more a year of abundance, although the number of spat was below that of 1926 . The older individuals seem to have died out very largely after spatting, and the percentage of spat to total population once more rose nearly to the 1926 figure of $80 \%$. These changes are: shown in Figures 1 to 13.

There are two seasons when mortality might be expected to be high, $(a)$ in winter amongst the spat and $(b)$ in summer after spatting, amongst the older specimens. Winter mortality amongst the spat seems to be comparatively slight. In Table $\mathrm{X}$ B the percentage of spat to total population 

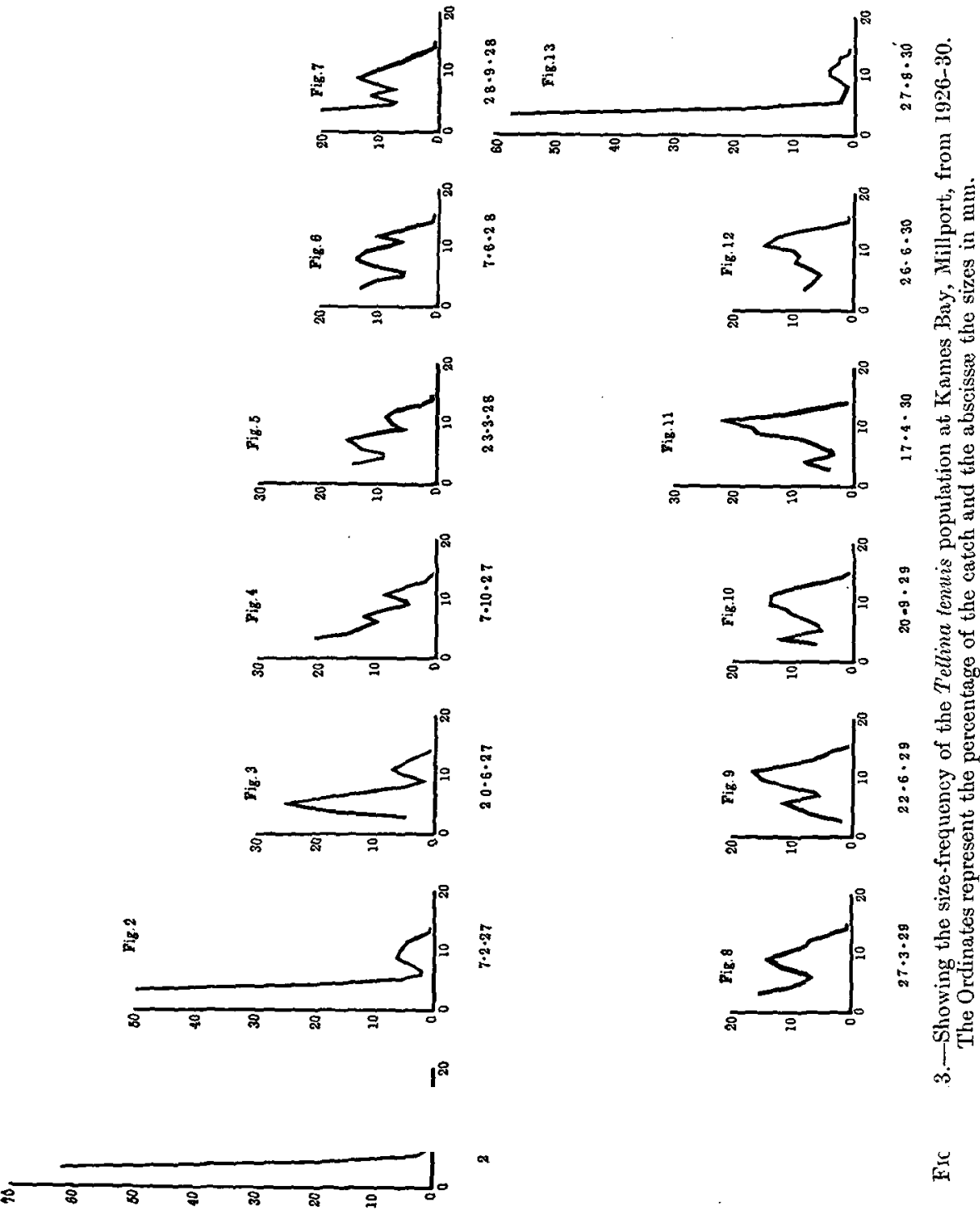

$\underline{\underline{u}}$ 
has been tabulated for autumn and spring. In each case the spring percentage is only a little less than the autumn one, and it is evident that the death-rate has been low. In the second case mortality after spatting is often very heavy, and a whole year-group may die off within a short period (pp. 294, 297).

\section{TABLE X.}

Showing the Percentage of Spat to Total Population in Autumn and Spring at Str. 5, Kames Bay, Millport.

A. AUTumn.

$\begin{array}{cccc}\text { Date. } & \begin{array}{c}\text { No. of Spat } \\ \text { per sq. m. }\end{array} & \begin{array}{c}\text { Total Tellina } \\ \text { Population } \\ \text { per sq. m. }\end{array} & \begin{array}{c}\text { \% of } \\ \text { Spat. }\end{array} \\ 24.9 .26 & 2620 & 3288 & 80 \\ 7.10 .27 & 1088 & 3056 & 36 \\ 28.9 .28 & 854 & 3038 & 28 \\ 20.9 .29 & 232 & 1348 & 17 \\ 27.8 .30 & 1628 & 2136 & 76\end{array}$

$\begin{array}{rrrr}13.4 .27 & 2664 & 3595 & 74 \\ 23.3 .28 & 716 & 2912 & 25 \\ 27.3 .29 & 508 & 2004 & 25 \\ 17.4 .30 & 156 & 1480 & 11\end{array}$

(b) Variation in Density of POPUlation.

In accordance with the variation in recruitment from unequal spattings coupled with the rise and decline of the 1926 spat, the density of population at Stn. 5 has fluctuated considerably during the period, as may be seen from Table XI.

\section{TABLE XI}

Showing the Variation in Density of Population per sQ. M. at STN. 5. (Owing to the great similarity of the figures for each of the collections during 1927 and 1928 the table has been shortened by giving the average for these years.)

\begin{tabular}{|c|c|c|c|c|c|c|c|c|}
\hline 24.9 .26 & . & & & & . & 3288 & per & $\mathrm{m} . \mathrm{m}$. \\
\hline 1927 (a) & erage) & . & & & & 3403 & , & $"$ \\
\hline 1928 & , & . & & . & & 2883 & ", & " \\
\hline 27.3.29 & . & . & & . & & 2004 & , & , \\
\hline 20.9 .29 & . & . & & & & 1348 & , & ", \\
\hline 17.4 .30 & . & . & & . & & 1480 & ", & " \\
\hline 26.6 .30 & . & . & & . & & 1094 & ", & , \\
\hline 27.8 .30 & . & . & & . & & 2136 & ," & 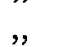 \\
\hline
\end{tabular}

NEW SERIES.-VOL. XVIr. NO. 2. JUNE, 1931. 
In the autumn of 1926 the density of population was over 3000 per sq. $\mathrm{m}$. During 1927 the figure was very much the same and dropped only slightly during 1928. From the autumn of 1928 onwards the fall was rapid, till by the middle of 1930 the density was just over 1000 per sq. m. In August the appearance of the new 1930 spat in large quantities almost doubled the density.

\section{(c) RISE AND DECLINE OF THE 1926 SPAT.}

As already stated, spat appeared in abundance in the autumn of 1926 and the survivors continued to be the dominant year-group until the summer of 1930, when, after spatting, they largely died out. This has been illustrated graphically in Figs.. 1-13. The figures from which these curves are drawn are given in Stephen, 3, for 1926-27, Stephen, 4, for 1928, and in Table XIII for 1929-30.

Judging by the modes, Table XII, this group seems to have reached its maximum size by the summer of 1929 .

\section{TABLE XII.}

Showing the Modes of the 1926 Spat at Stn. 5 for each time of Collection, 1926-1930.

\begin{tabular}{|c|c|c|c|}
\hline 24.9 .26 & $3 \mathrm{~mm}$. & 27.3 .29 & $9 \mathrm{~mm}$. \\
\hline 13.4 .27 & $3 \mathrm{~mm}$. & 22.6 .29 & $11 \mathrm{~mm}$. \\
\hline 20.6 .27 & $5 \mathrm{~mm}$. & 20.9 .29 & $11 \mathrm{~mm}$. \\
\hline 7.10 .27 & $7 \mathrm{~mm}$. & 17.4 .30 & $11 \mathrm{~mm}$. \\
\hline 23.3.28 & $7 \mathrm{~mm}$. & 26.6 .30 & $11 \mathrm{mr}$ \\
\hline 7.6 .28 & $8 \mathrm{~mm}$. & 27.8 .30 & $11 \mathrm{ml}$ \\
\hline 28.9 .28 & $9 \mathrm{~mm}$. & & \\
\hline
\end{tabular}

The story of the 1926 spat may therefore be summarised as follows :Spatted in the late summer of 1926, it was found in quantity at Stn. 5 in September, forming a well-defined peak on the size-frequency curve and comprising about $80 \%$ of the population. The modal size in September, 1926 , was $3 \mathrm{~mm}$., and by the autumn of 1927 this had increased to $7 \mathrm{~mm}$. By the autumn of 1928 it had reached $9 \mathrm{~mm}$., and by June, 1929, $11 \mathrm{~mm}$., at which figure it remained until the following year. In the first half of 1930 the ground was very largely populated by the 1926 spat, but by August the character of the population was completely changed. The individuals spatted in 1926 had largely died out and the 1930 spat had appeared in quantity. The percentage of spat to total population was. $76 \%$, that is, approximately, the 1926 figure, after an interval of four years.

The fate of the spat of the intervening years 1927-29 is of interest since the curves (Figs. 1-13) are largely bimodal and give the false impression that there are only two year-groups on the ground. 
In the autumn of 1927 spat came down in fair abundance and showed on the curves for the whole of the next year. The mode was at $3 \mathrm{~mm}$. in October, 1927 (Fig. 4), and March, 1928 (Fig. 5) ; 3 mm. in June (Fig. 6) ; and $6 \mathrm{~mm}$. in September (Fig. 7). From then onwards it seems to have disappeared entirely from the curves, having apparently failed to survive the winter.

In 1928 spat was also found in fair abundance. In September, 1928, it showed as a group with the mode at $3 \mathrm{~mm}$. (Fig. 7). The mode was at the same figure in March, 1929 (Fig. 8). In June the mode was at $6 \mathrm{~mm}$. (Fig. 9), and by September this spat had apparently overtaken the slowest growing individuals of the 1926 spat and the two curves merge into one, forming a composite group, the mode showing as an irregularity on the curve about $8-9 \mathrm{~mm}$. (Fig. 10). This irregularity continued to show on the curves until June, 1930 (Figs. 11 and 12), and it is presumed that the 1928 spat continued to survive until then. The spat in 1929 was very scarce and could not be traced on the curves for 1930 .

Rich spat-falls apparently occur only at intervals, and may produce a year-group which remains dominant on the ground for some years. Two factors probably combine to produce this result. There must, of course, be a specially abundant spat-fall, but the spat must also get a good start, for a poor start is apparently a handicap which is never overcome. For example, the spat of 1927 was more abundant than that of 1928, yet the spat of 1927 soon disappeared from the curves while the 1928 spat could be traced until June, 1930. A possible reason for this difference appears if the early history of each year-group is compared. Both ceased to grow during the winter and both started off with a mode of $3 \mathrm{~mm}$. in spring, but whereas the mode of the 1927 spat was still at $3 \mathrm{~mm}$. in June (1928) the mode of the 1928 spat was at $6 \mathrm{~mm}$. in June (1929). By the end of 1928 the mode of the 1927 spat had only reached $6 \mathrm{~mm}$. (equivalent to the June mode of the 1928 spat), while by the end of 1929 the 1928 spat had reached 8-9 mm. Apparently the adverse spring of 1928 had been a handicap to the 1927 spat from which it had never recovered. These interesting problems will be the subject of further investigation.

\section{TABLE XIII.}

Showing Percentage at each m. size for Tellina tenuis at Stin. 5, Kames Bay, 1929-1930.

\begin{tabular}{rrrrr}
3 & \multicolumn{1}{c}{4} & \multicolumn{1}{c}{5} & 6 & 7 \\
$15 \cdot 3$ & $10 \cdot 1$ & $8 \cdot 0$ & $6 \cdot 3$ & $7 \cdot 5$ \\
$1 \cdot 8$ & $6 \cdot 7$ & $8 \cdot 0$ & $10 \cdot 6$ & $5 \cdot 0$ \\
$5 \cdot 8$ & $11 \cdot 3$ & $4 \cdot 6$ & $5 \cdot 3$ & $7 \cdot 6$ \\
$3 \cdot 5$ & $7 \cdot 3$ & $3 \cdot 0$ & $3 \cdot 2$ & $6 \cdot 0$ \\
$8 \cdot 0$ & $6 \cdot 7$ & $6 \cdot 0$ & $5 \cdot 1$ & $6 \cdot 7$ \\
$57 \cdot 7$ & $18 \cdot 4$ & $2 \cdot 2$ & $2 \cdot 0$ & $1 \cdot 8$
\end{tabular}

$\begin{array}{lll}8 & 9 & 10\end{array}$




\section{Macoma baltica.}

RATE OF GROWTH AND TIME OF SPAT-FALL (FIGS. 14 AND 15).

An attempt has been made to estimate the rate of growth and time of spat-fall for this species. It is not very abundant in the Cumbrae area, but is plentiful in certain parts of the Firth of Forth. In Aberlady Bay, for example, where the species is relatively abundant, the density reaches about 150 to 200 per sq. m. in places. This bay was therefore chosen as a

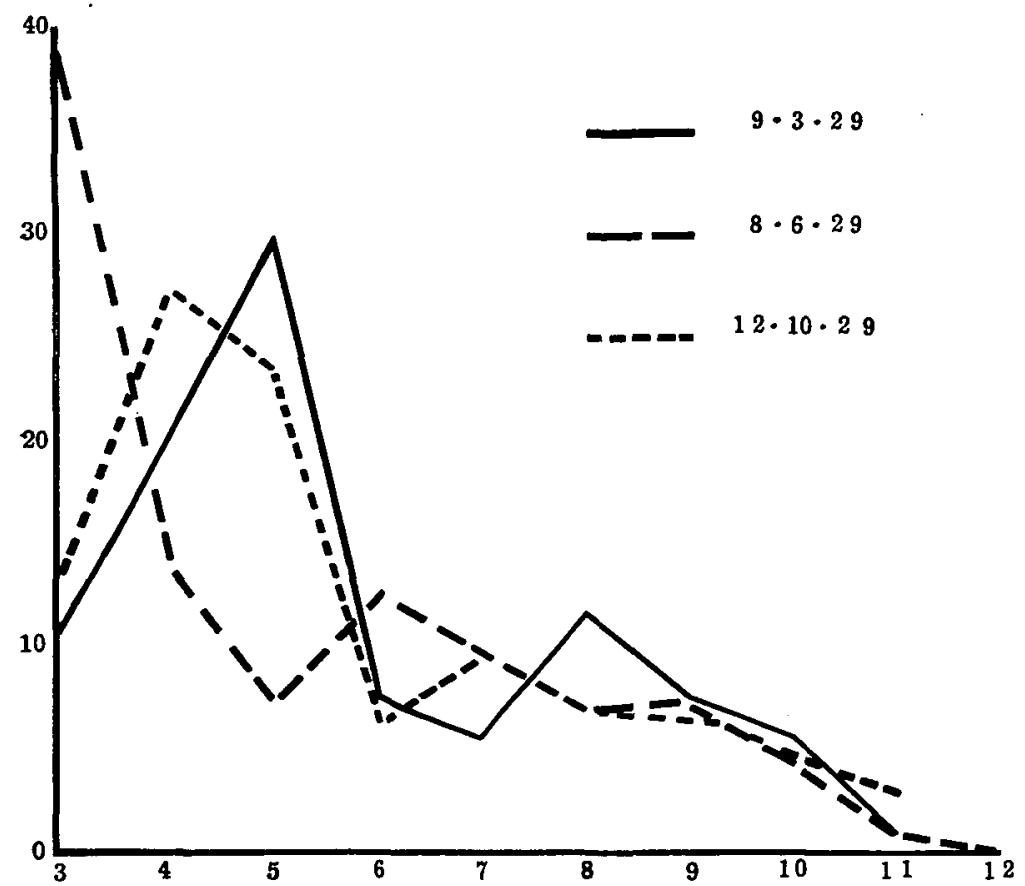

Fia. 14. - Showing the size-frequency curves for the collections of Macoma baltica taken in Aberlady Bay during 1929.

Ordinate percentage of the total catch. Abscissa size in mm.

suitable locality for study, and collections were made during 1929 and 1930 at one station about 100 yards from H.W.M.

In the spring of 1929 there were modes at $5 \mathrm{~mm}$. and $8 \mathrm{~mm}$. on the curve, representing, it may be assumed in the light of later knowledge, the 1928 and 1927 spat respectively. In the beginning of June the modes were at $3 \mathrm{~mm}$. and $6 \mathrm{~mm}$. with a hint of a third at $9 \mathrm{~mm}$. The mode at $3 \mathrm{~mm}$. represents the new 1929 spat, that at $6 \mathrm{~mm}$. the 1928 spat, and the mode at $9 \mathrm{~mm}$. the $1927 \mathrm{spat}$. The latter seemed to be dying off after the 
breeding season. In October the modes were at $4 \mathrm{~mm}$. and $7 \mathrm{~mm}$., the 927 group having apparently entirely disappeared.

Compared with the spring modes of 1929 , which may be taken as the equivalent of the October, 1928, modes, since growth ceases during the winter, the position of the modes in October, 1929, would point to growth having been slower than in the previous year, probably on account of the heavier spat-fall and therefore greater competition for food.

In 1930 growth among the smaller individuals had begun before the

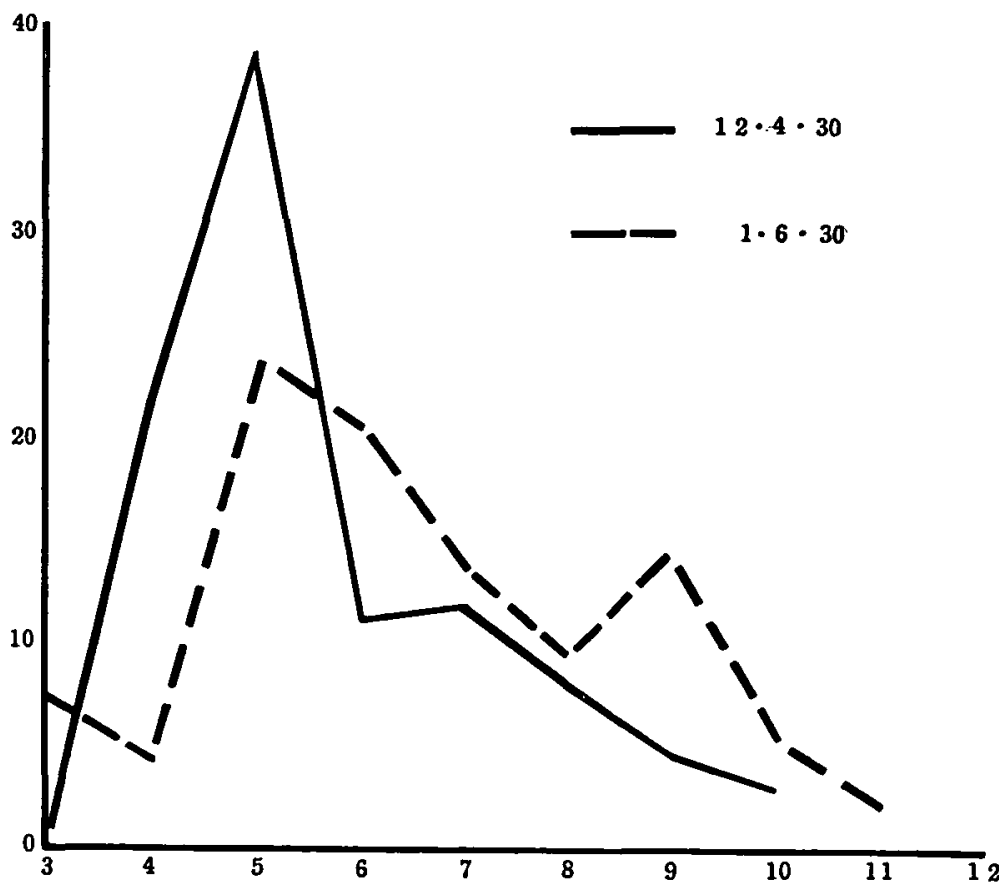

FIg. 15.-Showing the size-frequency curves for the collections of Macoma baltica taken in Aberlady Bay in 1930.

Ordinate percentage of the total catch. Abscissa size in $\mathrm{mm}$.

spring samples were taken, since the first mode had moved from $4 \mathrm{~mm}$. to $5 \mathrm{~mm}$. The second mode remained unaltered. On the June curve, as in the previous year, there were three modes at $3 \mathrm{~mm}$., $5 \mathrm{~mm}$., and $9 \mathrm{~mm}$., representing the new 1930 spat, the 1929 spat, and the 1928 spat respectively. Sampling was repeated on two occasions in October, but for several reasons the collections were unsatisfactory. The size-frequency curve for these small collections gave a hint of modes at $5 \mathrm{~mm}$. and $7 \mathrm{~mm}$., but it was impossible to judge if the oldest group had survived. 
Judging by the analogy of the previous year it had probably died out more or less completely after the breeding season.

To summarise. Macoma baltica apparently breeds in spring, and since spat was found in June of both the years 1929, 1930, the period April to May is suggested as the possible breeding period. The spat is well-grown before winter sets in. Judging by the modes the size at the end of the first autumn is about $5 \mathrm{~mm}$. and at the end of the second about 7-8 $\mathrm{mm}$. at this particular station. It would seem from the 1929 figures that mortality is heavy after spatting in the third summer. Breeding probably occurs earlier in life, but it is after this time that the large individuals tend to disappear in greatest numbers.

The year 1929 seems to have been a very favourable one for spat, since the average density of spat in June was about 150 per sq. m. On the other hand, the year 1930 seems to have been very poor, since the density in June of that year was only about 30 per sq. $\mathrm{m}$. The term "spat" in the above paragraph has been restricted to individuals up to $3 \mathrm{~mm}$. in length. The size-frequencies of the specimens taken in 1929 and 1930 are set out in Table XIV.

\section{TABLE XIV.}

Showing the Frequency at each mu. size for $M$. baltica in Aberlady Bay, Firth of Forth, during 1929 and 1930.

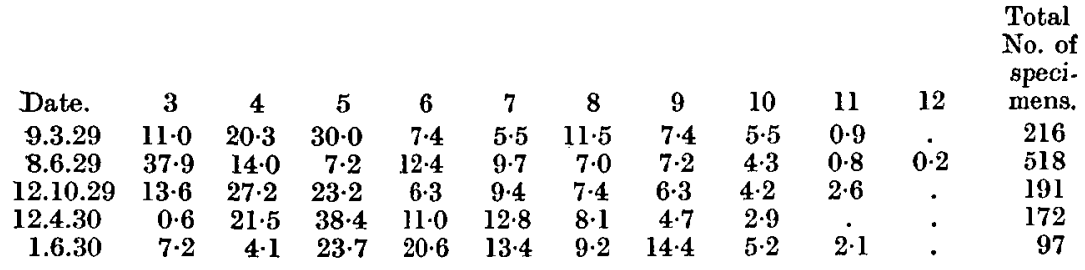

\section{SUMMARY.}

(a) CaRdium EDULe OR COCKLE.

1. The observations were made on the Hunterston Sands, Ayrshire, opposite the Cumbrae.

2. Small cockles appear on the ground about the beginning of August. This points to the breeding season being in summer and not spring, as is usually stated.

3. By the end of the first autumn some few of the spat are as much as $10 \mathrm{~mm}$. in length, but most are under $6 \mathrm{~mm}$. The winter ring is faint and easily overlooked. 
4. The first of the several well-defined rings is therefore not the first but the second winter ring.

5. Certain year-groups predominate. The specimens taken during 1929 and 1930 were largely the survivors of the 1926 spat.

6. The mean length of each of the winter rings has been tabulated for each year-group. These means tend to be higher in the older groups, pointing to mortality being heaviest amongst the slower growing individuals.

7. The size increases regularly from H.W.M. to L.W.M., due to an increased rate of growth. Growth is very fast amongst the scattered individuals living in the Tellina ground, that is, seawards of the cockle beds proper.

\section{TELLINA TENUIS.}

1. The variations in the annual spat-fall at Stn. 5 in Kames Bay from 1926-30 are traced. Some years give a rich spat, others only a poor spat, but the final contribution to the population may depend on other factors as well, e.g. a good growing start.

2. Mortality is comparatively light amongst the spat during winter, but may be exceedingly heavy after spatting amongst the adult population.

3. At Stn. 5 the group spatted in the autumn of 1926 remained the dominant year-group until the summer of 1930 .

4. The spat of 1930 was abundant and, owing to the heavy mortality amongst the adults after spatting, the type of size-frequency curve seen in September, 1926, was repeated, after an interval of four years.

MACOMA BALTICA.

1. The species was observed in Aberlady Bay, Firth of Forth.

2. Small individuals appear in June and the breeding period is probably April to May.

3. By the end of the first year the average size is about $5 \mathrm{~mm}$., and by the end of the second 8 to $9 \mathrm{~mm}$. The end of the breeding season in the third summer seems to mark the termination of the life of the average individual.

\section{Literature Cited.}

1. Johnstone, J. L.M.B.C. Memoir II. Cardium. 1899.

2. ORton, J. H. On the Rate of Growth of Cardium edule. Part I. Experimental Observations. Journ. Mar. Biol. Assoc., N.S., Vol. XIV, No. 2, 1926, p. 239. 
3. Stephen, A. C. Notes on the Biology of Tellina tenuis da Costa. Journ. Mar. Biol. Assoc., Vol. XV, No. 2, 1928, p. 683.

4. Stephen, A. C. Notes on the Rate of Growth of Tellina tenuis da Costa in the Firth of Clyde. Journ. Mar. Biol. Assoc., Vol. XVI, No. 1, 1929, p. 117.

5. Stephen, A. C. Studies on the Scottish Marine Fauna. Additional Observations on the Fauna of the Sandy and Muddy Areas of the Tidal Zone. Trans. Roy. Soc. Edin., Vol. LVI, Part II, No. 22, p. 521. 